\title{
Processing of Palm Mill Oil Effluent Using Photocatalytic: A Literature Review
}

\author{
Lya Agustina ${ }^{1,2^{*}}$, Suprihatin ${ }^{1 *}$, Muhammad Romli ${ }^{1}$, Prayoga Suryadarma ${ }^{1}$ \\ 1 Department of Agroindustrial Technology, Bogor Agricultural University (IPB) Bogor 16680, Indonesia \\ 2 Department of Agroindustrial Technology, University of Lambung Mangkurat, Banjarbaru 70714 Indonesia \\ *Corresponding author's e-mail: lya.agustina@ulm.ac.id; suprihatin167@gmail.com
}

\begin{abstract}
The extraction of palm oil fruit (E. guineensis) is achieved by a combination of methods such as pressing, sterilizing, digesting, peeling, grading, purifying, and vacuum drying the extracted oil. This process requires excessive use of water and produces a large amount of wastewater with a high concentration of pollutants, called palm oil mill efluent (POME). This waste water is a high-viscosity liquid with a brown color and a temperature of $80-90{ }^{\circ} \mathrm{C}$. It has a very low $\mathrm{pH}$ value, between $4.2-4.5$, has a high chemical and biochemical oxygen demand, and is extremely toxic. POME treatment has adopted a variety of methods and technologies, including coagulation-flocculation, anaerobic-aerobic treatment and membrane technology. Biological treatment is mainly used to treat POME, and the POME treated through biological treatment is called palm oil mill secondary effluent (POMSE). Unfortunately, the treated wastewater still contains high concentrations of organic matter. The color of the effluent is still dark brown. The remaining pollutants from this biological process are generally difficult to degrade biologically, thus requiring suitable processing methods for its removal, so that it can be discharged to the environment safely or even reused orrecycled. One of the challenging processing methods is photocatalytic process. This method is able to utilize abundant resources in the form of sunlight, and is also effective to degrade a wide variety of recalcitrant organic pollutants in the wastewater. This paper presents the current research and development of photocatalytic degradation process for processing of palm oil mill secndary effluent. The review and analysis are focused on synthesis of photocatalyst and the photoreactor design. Based on the results of the literature review and analysis, some recommendations are formulated for future research for their application in advanced POMSE management so that it can be reused for various purposes.
\end{abstract}

Keywords: POME, POMSE, photocatalytic, photoreactor design, synthesis of photocatalyst

\section{INTRODUCTION}

The crude palm oil (CPO) production has experienced a significant increase, it has grown 720,000 tons of crude palm oil production in 1980 , to 23 million tons production of CPO in 2011 [Rahayu et al., 2015]. Based on calculations estimated in 2020, 34 million tons of CPO will be produced from 9.1 million hectares of oil palm plants. However, based on Indonesian Palm Oil Association reflection on 2019 CPO production, is 51.8 million tons of CPO. This shows that the development of the palm oil industry is increasing rapidly and has exceeded estimates a few years ago. This increase in production must be accompanied by an increase in the amount of waste produced.

According to [Chang, 2014] reports, $1.5 \mathrm{~m}^{3}$ of water is required to extract fresh fruit bunches of palm fruit. The process is classification, pressing, sterilizing, digesting, purification, steam stripping, and also vacuum drying. Certain methods may require excess water, $50 \%$ of which will eventually become POME (palm oil mill effluent). Fresh POME actually is a highly viscous brown fluid with a warmth of $80-90{ }^{\circ} \mathrm{C}$ and a very low $\mathrm{pH}$ between 3.5 and 4.2 (shown in Table 1). The average amount of POME produced by palm oil mills 
is $58.3 \%$ with organic content chemical oxygen demand (COD) $50,000 \mathrm{mg} / \mathrm{L}$; biological oxygen demand (BOD) $30,000 \mathrm{mg} / \mathrm{L}$ and total suspended solid (TSS) 59,350 mg/L [Fadzil et al., 2013]. Based on Table 1, the highest waste discharge of POME is $2.5 \mathrm{~m}^{3}$ in every tonne of CPO produced by excellent operational practices. But other processing also shows that the amount of POME can be increase of about 3. per tonne of CPO if the processes are not well managed. We can conclude that waste discharge of POME may be decreased throughout good operational practices and milling [Tabassum et al., 2015].

The effluent that has been treated by biological treatment and is called the secondary effluent of the palm oil mill (POMSE) is still brown, with COD, BOD and TSS values as high as $1600 \mathrm{mg} / \mathrm{L}, 160 \mathrm{mg} / \mathrm{L}$ and 14,787 mg/L[Fadzil et al., 2013]. This effluent may pose a danger to aquatic organisms and human life. Because the high organic load of POMSE records COD discharge of more than $1000 \mathrm{mg} / \mathrm{L}$ into the water stream, the problem of eutrophic algae blooms [Subramaniam et al., 2017]. Eutrophication will cause the deterioration of water quality, which is manifested by the low transparency of water and the foul smell of POMSE. Therefore, it is obvious that non-biological treatment is needed to make the effluent reach environmental quality standards [Fadzil et al., 2013].

In Indonesia, considering economy and ease of operation, almost all palm oil processing plants use open pond systems to process POME. In the process of managing an open pond system, POME is guided through a series of ponds with multiple treatment steps [Rahayu et al., 2015]. Within the system, organic matter is largely integrated anaerobically and causes an odor and causes methane gas emissions [Sarono et al., 2016]. Based on economic reasons, the anaerobic wastewater treatment system has real advantages over the aerobic treatment system, which among others operates almost without additional energy, is able to reduce the weight of pollutants to moderate and formed sludge as a substitute for organic fertilizer (compost). The design of anaerobic renovation techniques in a pool system is usually a series of open ponds composed of several pools. The system is able to set aside BOD content up to $95 \%$, but in the long term ( 55 days to 110 days) so it requires a very large installation land [Ahmad et al., 2016].

Table 2 presents the treatment $\mathrm{s}$ for POME comparison, namely anaerobic, photocatalytic, membrane technology (MT) and aerobic. It can be seen that by using photocatalytic, the degradability of the process is adequate to $50 \%$ of the initial value (seen from the decrease in COD value). This shows that the photocatalytic technique can be use as an alternative for processing POME so that the resulting effluent can meet the environmental quality standards.

Photocatalytic have been studied as an alternative for wastewater treatment since 1970. Photocatalytic work to degrade recalcitrant compounds that have not been completely degraded using biological processes. The degradation ability can be seen from the ratio of COD /BOD an effluent, if the indicated ratio is $>3$ it is indicates the low degradability of an applied process. The basic principle of photocatalysis is to produce a highly oxidizing substance called hydroxyl radical $\bullet \mathrm{OH}$, which has an oxidation potential of $2.8 \mathrm{eV} \cdot \cdot \mathrm{OH}$ is a common free radical in water. Compared with other oxidants, it is one of the strongest oxidants. The reaction carried out by $\mathrm{OH}$ radicals is nonselective and fast. Basically, once $\cdot \mathrm{OH}$ is generated in situ, it will start to react by attacking the target pollutant, and in the presence of oxygen, it can achieve complete mineralization. The unique

Table 1. Parameters Limits of POME and POMSE

\begin{tabular}{|c|c|c|c|c|}
\hline Parameter & $\begin{array}{c}\text { The highest level } \\
\text { (mg/L) }\end{array}$ & Highest Pollution Load (kg/ton) & $\begin{array}{l}\text { POME** }^{* *}(\mathrm{mg} / \mathrm{L}) \\
\end{array}$ & $\begin{array}{c}\mathrm{POMSE}^{* *} \\
(\mathrm{mg} / \mathrm{L})\end{array}$ \\
\hline $\begin{array}{l}\text { BOD }_{5} \\
\text { COD } \\
\text { Suspended Solid } \\
\text { Fat and Oil } \\
\text { Total Nitrogen Total }{ }^{* * *} \text { (as N) }\end{array}$ & $\begin{array}{c}100 \\
350 \\
250 \\
25 \\
50\end{array}$ & $\begin{array}{c}0.25 \\
0.88 \\
0.63 \\
0.063 \\
0.125\end{array}$ & $\begin{array}{l}30000 \\
50000 \\
59350\end{array}$ & $\begin{array}{c}160 \\
1600 \\
14787\end{array}$ \\
\hline $\mathrm{pH}$ & \multicolumn{2}{|r|}{$6.0-9.0$} & 4.5 & 9.0 \\
\hline $\begin{array}{l}\text { The Highest Waste } \\
\text { Discharge }\end{array}$ & \multicolumn{2}{|c|}{$2.5 \mathrm{~m}^{2}$ per tonne of palm oil product (CPO) } & & \\
\hline
\end{tabular}

Source: * Minister of Environment Regulation No. 5 of $2014 * *$ [Alhaji et al., 2016]

$* * *$ Total Nitrogen: Organic Nitrogen + Total Ammonia Total $+\mathrm{NO}_{3-}{ }^{+}-\mathrm{N}+-\mathrm{NO}_{2}-\mathrm{N}$. 
Table 2. Various advanced processing methods comparison for chosen parameters in POME [Vijayaraghavan et al., 2007; Wang et al., 2015; Ng et al., 2015]

\begin{tabular}{|c|c|c|c|c|c|c|c|c|c|}
\hline \multirow{2}{*}{ Parameters } & \multirow{2}{*}{ Standards } & \multicolumn{2}{|c|}{ Aerobic } & \multicolumn{2}{|c|}{ Anaerobic } & \multicolumn{2}{|c|}{ MT } & \multicolumn{2}{|c|}{ Photocatalytic } \\
\hline & & Before & After & Before & After & Before & After & Before & After \\
\hline COD (mg/L) & 350 & 4580 & 3908 & 3507 & 2694 & 258 & 150.46 & 60 & 37 \\
\hline BOD5 (mg/L) & 100 & 2060 & 1720 & 450 & 333 & 420 & 360 & 55 & 40 \\
\hline $\mathrm{pH}$ & $6.0-9.0$ & 7.0 & 8.0 & 6.6 & 7.3 & 7.0 & 8.0 & - & - \\
\hline Grease and oil (mg/L) & 25 & - & - & - & - & - & - & - & - \\
\hline Suspended solid (mg/L) & 250 & - & - & - & - & 70 & 50 & 220 & 150 \\
\hline
\end{tabular}

feature of photocatalysis is that it can be used to generate $\mathrm{OH}$ in a flexible way and does not involve phase transfer when treating wastewater. Therefore, the more $\cdot \mathrm{OH}$ generated, the better. Equations (1) to (9) describe the general mechanism of photocatalysis [12].

$$
\begin{aligned}
& \mathrm{TiO}_{2}+\mathrm{UV} \rightarrow \mathrm{TiO}_{2}(e-\mathrm{CB}+h+\mathrm{VB}) \\
& \mathrm{TiO}_{2}(h+\mathrm{VB})+\mathrm{H}_{2} \mathrm{O} \rightarrow \mathrm{TiO}_{2}+\mathrm{H}++\mathrm{OH} \bullet \\
& \mathrm{TiO}_{2}(h+\mathrm{VB})+\mathrm{OH}-\rightarrow \mathrm{TiO}_{2}+\mathrm{OH} \bullet \\
& \mathrm{O}_{2}+e-\mathrm{CB} \rightarrow \mathrm{O}_{2}^{-} \bullet \\
& \mathrm{O}_{2}-\bullet+\mathrm{H} \mathrm{O}_{2} \rightarrow \mathrm{H}_{2} \mathrm{O}_{2} \\
& \mathrm{H}_{2} \mathrm{O}_{2} \rightarrow 2 \mathrm{OH} \bullet \\
& \text { Dye }+\mathrm{OH} \bullet \rightarrow \text { Products of degradation }
\end{aligned}
$$

$$
\text { Dye }+h+\mathrm{VB} \rightarrow \text { Oxidation results }
$$

$$
\text { Dye }+e-\mathrm{CB} \rightarrow \text { Reduction results }
$$

In order to react effectively, pollutants, catalysts and lighting sources need to be close to or in contact with each other [Ibhadon \& Suprihanto, 2015]. Some of the benefits of using photocatalytic technology are complete and complete mineralization [Alhaji et al., 2016], without producing a large amount of sludge [Akpan \& Hameed, 2009], its reaction speed is also very fast, it is cost-effective [Chang \& Nae, 2010] and environmentally friendly. As we all know, the photocatalytic process is a technology that can be applied to waste treatment in a relatively simple way. The success of this technology depends largely on the light wavelength, reactor design, photocatalyst loading, light intensity, and reactants' initial concentration. The $\mathrm{pH}$, ion-ion existence, temperature, and oxygen content. The purpose of this article is to examine the research progress related to the photocatalytic process, which is mainly carried out in the design of the reactor and the synthesis of the photocatalyst used.

\section{PHOTOCATALYTIC}

A collection of research were accomplished associated with the utility of photocatalytic for wastewater treatment. Photocatalytic can degrade organic and inorganic compounds which are tough to be degraded biologically. Recent traits withinside the area of photocatalytic water treatment using nanocrystalline titanium dioxide (NTO) has describe with the aid of using [Lazar et al., 2012]. Selective photocatalysis with the aid of using NTO with its degradation kinetics is a capacity studies region wherein researchers can discover numerous opportunities. It is likewise essential to expand capacity coupling NTO photocatalysis with different technologies. Some research about codoping of photocatalyst was held, according to Thota et al. [2014], codoping $\mathrm{TiO}_{2}$ with nitrogen and manganese $(0.75$ wt. $\% \mathrm{~N}$ and $0.25 \mathrm{wt} . \% \mathrm{Mn}-\mathrm{TiO}_{2}$ ) as a promising direction for improved pollutants' photocatalytic degradation (100\% methyl red degradation with $5 \mathrm{mg} / \mathrm{L}$ initial concentration become completed during $90 \mathrm{~min}$ at $\mathrm{pH} 4$ with $2.0 \mathrm{~g} / \mathrm{L}$ catalyst dosage). Ali et al. [2014] has studies that $10 \mathrm{wt} \% \mathrm{ZnO}-\mathrm{SiO}_{2}$ tempered at $600{ }^{\circ} \mathrm{C}$ confirmed the best photocatalytic activity to the Methylene-Blue photodegradation. Li et al. [2014] observed that $\mathrm{TiO}_{2}$-lined silica gel beads immobilized DCS photoreactor confirmed 
better efficiency, decrease power intake and higher constant operation overall completion for the rhodamin $\mathrm{B}(\mathrm{RhB})$ and methyl orange (MO) degradation. Ong et al. [Ong et al., 2016] has studied approximately congo red degradation the usage of $\mathrm{ZnO}$, the degradation become higher in acidic condition. According to a few studies which have been established, Khan et al. [2015] look at approximately steel oxides interpretation as the photocatalyst, structural characteristics, photocatalyst needs and category as well as the mechanism process.

Some evaluate of latest improvement approximately photocatalytic additionally discuss, photocatalytic degradation era for POME [Alhaji et al., 2016], latest tendencies withinside the studies and heterogeneous semiconductor photocatalytic alertness for treatment of low-degree pollution concentrations in air and water the use of titanium dioxide as semiconductor "model" [Ibhadon $\&$ Suprihanto, 2015] and additionally a evaluate of photocatalytic membran reactor (PCMR) era became held by [Kumari et al., 2020].

Several research associated with the implementation of photocatalytic in palm oil wastewater may be described. The whole COD elimination became done via way of means of this device (Two steps UV/ Ferrioxalate/ $\mathrm{TiO}_{2}$ system treatment for 2 hours accompanied by UV/ $\mathrm{O}^{3}$ as subsequent hours) and the physical look of POMSE became colorless [Fadzil et al., 2013]. POME became degraded beyond the $\mathrm{Ag} / \mathrm{TiO}_{2}$ beneathneath seen mild irradiation. POME degradation of $26.77 \%$ became done with $1.5 \mathrm{~g} / \mathrm{L}$ and $70 \mathrm{~mL} / \mathrm{min}$ of $0.5 \mathrm{wt} \% \mathrm{Ag} / \mathrm{TiO}_{2}$ and $\mathrm{O}_{2}$ flow rate [Ng et al., 2015]. Tan et al. [2014] describe those $10 \mathrm{wt} \%$ suspended nanoparticles of $\mathrm{TiO}_{2}$ can do away with greater than $70 \%$ of the colour pigment in AT-POME.

Lestari has determined that $\mathrm{TiO}_{2}$ photocatalysts are capable of degrading organic composites and get rid effectively of phenol pollution in POMSE (degradation overall performance is $31.36 \%$ and phenol removal as much as $96.66 \%$ $\left(\mathrm{TiO}_{2}\right.$ loading $=1.5 \mathrm{~g} / \mathrm{L}$; air flow rate $\left.=10 \mathrm{cc} / \mathrm{min}\right)$ at $120^{\text {th }}$ minute). The capacity of $\mathrm{TiO}_{2}$ photocatalysts to degrade organic compounds is pretty solid withinside the variety $25.25-31.36 \%$ for 2 hours (COD POMSE is 250 to $650 \mathrm{ppm}$ ) [Lestari, 2017]. A submerged membrane photoreactor (SMPR) has substantially decreased the polyvinylidine flouride/titanate nanotube (PVDF-TNT) layers' fouling susceptibility, in which flux lack of most effective $5.7 \%$ turned into discovered after five circles of usage, the shade elimination is $67.3 \%$ [Subramaniam et al., 2017]. ZnO polyethylene glycol (ZnO-PEG) nanoparticles hold an extremely good capacity in degradation of POMSE (photocatalysts) $66 \%$, (pH) 73\%, (ZnO-PEG loading) $84 \%$ and (awareness of POMSE) 84\%. POMSE's photocatalytic degradation system is below pH 6.5 in every $0.5 \mathrm{~g} / \mathrm{L} \mathrm{ZnO-PEG} \mathrm{for} \mathrm{the} 50 \%$ of POMSE dilution [Zainuri et al., 2018]. $\mathrm{LaCa}$ (3 $\mathrm{wt} \%$ of La doped in Ca900 (calcium oxide)) as an opportunity photocatalyst because of extra greener and got here from renewable feedstock to update present photocatalyst. The photodegradation of POME suggests elimination percent at $54.09 \%$ [Ghazali et al., 2018]. An optimized Photocatalytic Fuel Cell (PFC) system with anodic TZ2 below the situations of $0.3 \mathrm{M} \mathrm{KOH}$ assisting electrolyte, $100 \mathrm{mgL}^{-1}$ of preliminary POME awareness and herbal $\mathrm{pH}$ of 8.35 turned into installed to be the maximum promising PFC gadget (COD elimination of POME as much as $89 \%$ with Voc, JSC and Pmax of $1173 \mathrm{mV}, 0.2652 \mathrm{mAcm}^{-2}$ and $0.0734 \mathrm{mWcm}^{-2}$ ) [Kee et al., 2019].

$\mathrm{Ng}$ et al. insights toward the photocatalytic process feasibility, and flexibility and performance proposed photocatalysts $\left(\mathrm{TiO}_{2}\right.$ and $\left.\mathrm{ZnO}\right)$ for POME cotreatment for renewable power production $[\mathrm{Ng}$ et al., 2019]. Nanofiltration membrane (NF-TS 40) membrane could enhance the membrane fouling mechanism withinside the second step which sooner or later help the POMSE treatment effectiveness through photocatalytic membrane reactor (PMR) in phrases of coloration removal (99.84\%), turbidity removal (99.89\%), BOD (96.24\%), and COD (98.97\%) [Sidik et al., 2019].

The description above shows that research on the process of photocatalytic is not a new thing to do. The photocatalytic can be applied to a variety of wastewater with varying results. Photocatalytic is characterized by looking at: (1) great activity, (2) resistance to long-term use durability at elevated temperatures, (3) mechanical durability and erosion resistance, (4) lacks selectivity in some respects, and (5) stability of physics and chemistry under various conditions [Salsabila, 2016]. In its application, it is expected not only to use UV light but also visible light so it is not expensive. According to [Hermann, 2005], factors that can influence photocatalytic include: reactor design, wavelength and intensity of light, photocatalyst loading, temperature, reactant initial concentration, ions existence, oxygen content, and $\mathrm{pH}$. 


\section{PHOTOREACTOR}

There are two basic kinds of photoreactor that is used for degradation, immobilized and slurry. Advantages and disadvantages of those kind of photoreactor are describe below (Table 3), these can be carried out into consideration so the benefits could be explored for the efficient POME degradation.

Development of photocatalytic was reviewed by [Hermann, 2005]. A series of studies that have been carried out related to the photoreactor used in the photocatalysis process will discuss. The $50 \%$ composition of dye pollution in water turned into evaluated using a rotating disk reactor (RDR). Photocatalyst $\left(\mathrm{TiO}_{2}\right)$ is immobilized on a disk (diameter of $6 \mathrm{~cm}$ ), and dye (methyl orange) containing answer is permitted to go with the drift in radial path alongside the disk surface, that is twisting and illumined using UV mild [Chang \& Nae, 2010]. A novel photoreactor device including a corrugated drum coating by $\mathrm{TiO}_{2}$ and a UV light supply is empirically identified for the phenol-polluted wastewaters treatment. The basic response fee expanded with growing surface location from $0.046 \mathrm{mg} / \mathrm{L} / \mathrm{min}$ for the annular drum to $0.16 \mathrm{mg} / \mathrm{L} / \mathrm{min}$ for the 40 fin drum. The power efficiency $(\mathrm{EE} / \mathrm{O})$ observed for the drums various from $380-550 \mathrm{kWh} / \mathrm{m} 3$, that is as much as $49 \%$ extra power-green than the annular drum [Meunier et al., 2010].

A fixed-bed continous annular reactor through the usage of a home-organized $\mathrm{TiO}_{2}$ catalyst became used on the photocatalytic oxidation of 4-methoxybenzyl alcohol in water. The effects imply that the partial oxidation pathway is desired through the photons' low flux absorbed and $\mathrm{TiO}_{2}$ surface's low oxygen insurance; contrary situations prefer the mineralization pathway [Yurdakal et al., 2010]. The maximum fee of deterioration became acquired for malachite green (MG) dye and the dyes' percent degradation order became $\mathrm{MG}>\mathrm{RhB}>\mathrm{MB}$ the usage of UV-LED supply and $\mathrm{TiO}_{2}$ system. [Natarajan et al., 2011]. The system accommodates a microcirculating fluid pump, UV-LED photoreactor, and in-flow sensor unit (includes a fluid flow cell with obvious windows) can degrade methyl orange [Nickels et al., 2012]. Removal performance of the MO degradation the usage of the capilarry array photocatalytic reactor (CAPCR) (120 min, $5 \times 10^{-5} \mathrm{moll}^{-1}$ of MO, 95,8\%) became higher than that during a traditional batch reactor with $\mathrm{P}-25 \mathrm{TiO}_{2}$ powder and $\mathrm{TiO}_{2}$ film immobilized directly to a quartz tube [Zhang et al., 2012]. According to Jamali et al. the mixture of UV LED with titanium dioxide is suitable for water treatment in degrading organic pollution at low concentrations [Jamali et al., 2013].

The using of a computational fluid dynamics (CFD) package deal confirmed adverse behaviors for the relative catalytic vicinity in keeping with unit window vicinity and the related occurrence flux with the folding perspective. Given that the internal occurrence performance incorporates the manufactured from the 2 noted variables, an most beneficial folding perspective become identified [Passalia et al., 2013]. A easy version for immobilized photocatalytic microreactors following a primary order response price with both independency and dependency of light defined via way of means of photon

Table 3. The comparison of slurry and immobilized Photoreactor [Qi et al., 2011; Fathinia \& Khataee, 2013; Vela et al., 2014; Li et al., 2014; Santiago et al., 2015]

\begin{tabular}{|c|c|c|}
\hline Reactors & Advantages & Disadvantages \\
\hline $\begin{array}{l}\text { Slurry } \\
\text { photoreactor }\end{array}$ & $\begin{array}{l}\text { - An excessive ratio of catalyst's illuminated surface to the } \\
\text { powerful reactor extent may be finished for a little well- } \\
\text { designed photocatalytic reactor. } \\
\text { - There isn't any mass switch obstacle exist because the } \\
\text { most diffusional distance could be very small as a result of } \\
\text { the usage of ultra-fine }(<30 \mathrm{~nm}) \text { catalyst particle } \\
\text { - Re-useable filter }\end{array}$ & $\begin{array}{l}\text { - The catalyst particle should be filtered } \\
\text { previous to the release of the handled } \\
\text { water. } \\
\text { - The UV light penetration intensity is } \\
\text { restricted because of robust absorption } \\
\text { through } \mathrm{TiO}_{2} \text { and diluted organics material. }\end{array}$ \\
\hline $\begin{array}{l}\text { Immobilized } \\
\text { photoreactor }\end{array}$ & $\begin{array}{l}\text { - No need separation and can be continuously treated. } \\
\text { - The degradation of contaminant molecules is increase } \\
\text { because of the large surface of catalyst film porous. } \\
\text { - While a conductive fabric is applied as support, the } \\
\text { catalyst movie may be related to an outside capability to } \\
\text { lessen electron-hollow recombination via way of means } \\
\text { of doing away with excited electrons, thereby notably } \\
\text { enhancing efficiency. }\end{array}$ & $\begin{array}{l}\text { - The catalytic surface accessibility to the } \\
\text { photons and the reactants, as well as } \\
\text { the tremendous impact of outside mass } \\
\text { transfer, mainly at below liquid glide rate, } \\
\text { because of the growing diffusional period } \\
\text { of reactant from bulk technique to the } \\
\text { catalyst surface. } \\
\text { - The internal mass transfer maybe limited } \\
\text { by the increase of the thickness of catalyst } \\
\text { film. }\end{array}$ \\
\hline
\end{tabular}


absorption service technology semiconductor physics via way of means of Visan et al. [2014]. Doss et al. [2018] describe a system incorporating 56 LEDs transmitting at $392 \mathrm{~nm}$ the use of $\mathrm{TiO}_{2}$ MPT623 (a noticeable light-responsive Pt chloride-changed rutile $\mathrm{TiO}_{2}$ photocatalyst) become a terrific compromise in phrases of MEK (methylethylketone) degradation performance and of power effectiveness.

The evolved flat plate dependent bed photoreactor changed into capable of perform in nonstop mode the use of optimized $\mathrm{N}$-doped $\mathrm{TiO}_{2}$ photocatalyst immobilized [Vaiano et al., 2015]. Khademalrasool et al. [2016] studied approximately photocatalytic response below the UVLEDs and conventional fluorescent UV lamps. The consequences confirmed that the charge of photocatalytic response below the UV-LEDs changed into instances more than the charge below the conventional fluorescent UV lamps, whilst each electric energy intake and production value of the power LED photoreactor (HPLED$\mathrm{PhR}$ ) have been much less than quarter of them for the flourescent lamp photoreactor (FL-PhR) [Khademalrasool et al., 2016]. The methylene blue, direct blue-15 malachite green, and amaranth dye degradation changed into received $93 \%, 94 \% 88 \%$, and $85 \%$ respectively the use of the $\mathrm{TiO}_{2}$ coated mosquito net below ultraviolet mild irradiation during four $\mathrm{h}$ through the use of easy photocatalytic reactor the use of $\mathrm{TiO}_{2}$ coated mosquito net and ultraviolet mild emitting diodes (UVLEDs) [Jo \& Rajesh, 2016].

Mirzaei et al. tested that entire phenol elimination turned into finished the usage of rotational disc for clean and baffled discs after 180 and 150 min of response time, which turned into 60 and 90 min quicker than the reactor with clean disc beneathneath most reliable circumstance of the reactor (rotational disc $=290 \mathrm{rpm}$, go with the drift price $=2000 \mathrm{~mL} / \mathrm{min}$, disc diameter $=$ $22 \mathrm{~cm}$ ) [Mirzaei et al., 2017]. A tiny size flowthrough photocatalytic tool consolidating a medium surface range, big cell-size $\beta$-SiC alveolar foam as a based photocatalyst $\left(\mathrm{TiO}_{2}\right.$ MPT623) guide and LEDs (56 LEDs emitting at $392 \mathrm{~nm}$ ) as an irradiation mild supply has been managed to broaden an air-purifying generation this is green at decontaminating airborne $\mathrm{T} 2$ bacteriophage viruses [Doss et al., 2018]. The elimination of crystal violet (CV) from aqueous samples the usage of $\mathrm{ZnO}$ immobilized on spherical pellets of zeolite (ZEO) with the goal to couple adsorption and photocatalytic.the aggregate of adsorption/photocatalytic turned into capable of achieve a regular country $\mathrm{CV}$ elimination of approximately $51 \%$ after $350 \mathrm{~min}$ of run time with a fluid go with the drift price of $4.2 \mathrm{~mL} / \mathrm{min}$ the usage of non-stop go with the drift micro-reactor [Sacco et al., 2018].

Photocatalytic technique in microreactor become studied, the possible rate constant $(\mathrm{k})$ of the reactor for every incoming irradiance of $191 \mathrm{~W} \mathrm{~m}^{-2}$ become observed to $0.82 \mathrm{~min}^{-1}$, as our understanding, withinside the microreactors variety and 1-2 significance orders better than any excessive throughput immobilized reactor in literature. Photocatalytic area-time yield of $0.657 \mathrm{~m}^{3}$ day $^{-1} \mathrm{~m}^{-3}$ reactor $\mathrm{kW}^{-1}$ our reactor become among the quality said performers in productiveness phrases and power efficiency. This is associated with the excessive precise illuminated floor region of $4267 \mathrm{~m}^{2} \mathrm{~m}^{-3}$ and excessive catalyst load of $1.9 \mathrm{~g} \mathrm{~L}^{-1}$ [Claes et al., 2019]. Kanmani and Sundar has reviewed there are 5 benchmark values are estimated for 24 reactors: Space-time yield (STP), Apparent rate constant (k), Specific removal rate (SRR) Photocatalytic space-time yield (PSTY), and Electrical energy consumption (EEC). And then, critical parameters should be balanced: technical viability (consists of excessive throughput and overall performance (mass transfer)) and budget friendly feasibility (power efficiency (photon transfer) and cost). For a powerful photocatalytic technique the technique parameters (dissolved oxygen, UV light intensity, sort of pollutant, pollutant concentration, temperature, flow rate, irradiation time, ozonation, hydrogen peroxide, catalyst load, airflow rate, $\mathrm{pH})$ must be correlated and thoroughly selected with the light source wavelength, photocatalyst's band hole power and pollutant absorption wavelength [Khanmani \& Sundar, 2019]. Visan et al. [2019] has overviewed of the underlying physics of photocatalytic reactions, even as specializing in pertinent hypothesis, and speak the results for the maximum simple reactor designs for which hints and standards are furnished to fulfill their premise.

\section{SYNTHESIS OF PHOTOCATALYST}

Many forms of metallic oxides inclusive of zinc sulfide $(\mathrm{ZnS})$, tin dioxide $\left(\mathrm{SnO}_{2}\right)$, cadmium sulphide $(\mathrm{CdS})$, iron oxide $\left(\mathrm{Fe}_{2} \mathrm{O}_{3}\right)$, titanium 
oxide $\left(\mathrm{TiO}_{2}\right)$, and zinc oxide $(\mathrm{ZnO})$ were used as catalysts withinside the photocatalysis process, for diverse forms of wastewater treatment [Sidik et al., 2019; Ong et al., 2016; Khan et al., 2015]. In order to gain higher photocatalytic degradation overall performance, smaller particle are recommended, to offer a much broader floor vicinity for the reaction. Research through [28] found out that $\mathrm{ZnO}$ nanoparticles are taken into consideration as a higher opportunity to $\mathrm{TiO}_{2}$ due to the sensitivity of the photocatalytic process, chemical stability, better reactivity and floor vicinity, excessive catalytic activity, and comparatively low costs. The overall $\mathrm{ZnO}$ nanoparticles performance in photocatalytic degradation is inspired through $\mathrm{ZnO}$ traits inclusive of morphology, size, and practise techniques for synthesizing $\mathrm{ZnO}$ nanoparticles. The nanoparticle material shows potential as a catalyst because the nanoparticle material has a large surface area and atomic ratios that are spread evenly on its surface, this property is advantageous for mass transfer in pores and also contributes a large interface to adsorption reactions and catalytic.

The development of nanoparticles basically involves three aspects, namely the exploration of raw materials and the selection of synthesis methods, the synthesis of the nanoparticles themselves, their characterization and application. Various synthesis methods have been developed by physical, chemical and biological methods. Some chemical methods include coprecipitation, sol-gel, electrochemical, hydrothermal, spray drying. However, these methods are burdened with various problems including the use of hazardous chemicals, expensive chemicals and high energy consumption. Synthesis of nanoparticles with these methods requires approximately three categories of materials, namely precursors (Anode (metal), $\mathrm{PdCl}_{2}, \mathrm{~K}_{2} \mathrm{PtCl}_{4}, \mathrm{AgNO}_{3}, \mathrm{HAuCl}_{4}$, $\left.\mathrm{RhCl}^{3}\right)$, reducing agents $\left(\mathrm{H}_{2}\right.$, Sodium Citrate, Citric Acid, CO, Methanol, Formaldehyde, $\mathrm{H}_{2} \mathrm{O}_{2}$, Sodium tetrathydroborate, and stabilizing agents (PVA and PVP).

The synthesis method of nanoparticle may be take physically or chemically in solid, liquid or gas phases. The physical synthesis method is simplest the breakdown of big material into nanometer-sized material, or the incorporation of very small-sized materials, including clusters, into nanometer-sized particle without converting the residences of the material. The chemical synthesis method entails the chemical response of some of beginning materials (precursors) to supply some other nanometer-sized material. Table 4 shows the development of research that has been done related to the synthesis of nanoparticles for photocatalysts.

Table 4. Research on synthesis of photocatalyst

\begin{tabular}{|c|c|c|c|}
\hline No & Author & Results & Year \\
\hline 1 & Xing et al. [2012] & $\begin{array}{l}\text { PE primarily based totally film consolidating with } \mathrm{TiO}_{2} \text { nanoparticles have an } \\
\text { awesome capability for use as lively food packaging system (proven through the } \\
\text { price of water vapor transmission accelerated of } 18.1 \text { to } 24.6 \mathrm{~g} / \mathrm{m}^{2} \cdot 24 \mathrm{~h} \text { ) }\end{array}$ & 2012 \\
\hline 2 & Chokriwal et al. [2014] & $\begin{array}{l}\text { Review of the recent developments of the biosynthesis mechanisms of different } \\
\text { types of nanoparticles using bacteria. }\end{array}$ & 2014 \\
\hline 3 & Shah et al. [2015] & The significant potential of biological synthesis via nanobiotechnology. & 2015 \\
\hline 4 & Amini et al. [2016] & The ZnO's catalytic activity on the system for dyes photodegradation. & 2016 \\
\hline 5 & Adhikari et al. [2016] & $\begin{array}{l}\text { The photocatalytic activity below solar light irradiation in contrast to } \mathrm{P}-25 \mathrm{TiO}_{2} \\
\text { using Spongy- } \mathrm{ZnO} \text {. }\end{array}$ & 2016 \\
\hline 6 & Ghosh et al. [2017] & $\begin{array}{l}\text { Review of manufacturing high-cost nanoparticles from food waste (aquaculture } \\
\text { and horticulture), inclusive of experimental parameters, nanoparticle traits and } \\
\text { capability packages for nanoparticles in prescription drugs and biomedical } \\
\text { packages. }\end{array}$ & 2017 \\
\hline 7 & Fajaroh [2018] & $\begin{array}{l}\text { Review of synthesis nanoparticle with environmentally and sustainable } \\
\text { technologies that by utilize natural reducers (plant extracts, food waste, } \\
\text { agricultural waste and microorganism) }\end{array}$ & 2018 \\
\hline 8 & $\begin{array}{l}\text { Muthuvinothini et al. } \\
\text { [2018] }\end{array}$ & $\begin{array}{l}\text { The used of catalysts for the reduce of fragrant aldehydes, the use of synthesized } \\
\text { MO nanoparticles at slight response situations, the use of ammonium formate as } \\
\text { a inexperienced hydrogen donor received in } 2-24 \text { h with notable yields. }\end{array}$ & 2018 \\
\hline 9 & Rekha et al. [2019] & $\begin{array}{l}\mathrm{TiO}_{2} \mathrm{NPs} \text { were synthesized from } \mathrm{TiCl}_{4} \text { applying antimicrobial peptide crustin for } \\
\text { the water-polluting dyes decrease. }\end{array}$ & 2019 \\
\hline 10 & Bandeira et al. [2020] & $\begin{array}{l}\text { Current review of the different sources of biological substrates and } \\
\text { methodologies applied to the green synthesis of zinc oxide nanoparticles and the } \\
\text { influence on their properties }\end{array}$ & 2020 \\
\hline
\end{tabular}




\section{CONCLUSION}

Photocatalytic is characterized by an environmentally friendly and cost-effective process for various pollutants removal in POMSE, including colour, recalcitrant organic and some inorganic substances. The photocatalytic process for further processing POMSE can use UV light or take advantage of sunlight which is very abundant in Indonesia. The significant factors of the photocatalytic process include: reactor design, wavelength and intensity of light, temperature, photocatalyst loading, $\mathrm{pH}$, initial reactant concentration, oxygen content, and the ions existence. The potentials for future research are identified as follows: (i) Modification of the photocatalytic reactor in accordance with the characteristics of the wastewater to be treated, especially POMSE; (ii) Synthesis of more suitable, effective, efficient and greener materials as photocatalyst nanoparticle catalysts show high potential for this purposes.

\section{Acknowledgements}

Research related to this topic is funded by a grant from the Deputy for Strengthening Research and Development, Ministry of Research and Technology-National Research and Innovation Agency, Republic of Indonesia.

\section{REFERENCES}

1. Adhikari S.R., Gupta A., Surin T.S., Kumar S., Chakraborty D., Sarkar G., Madras. 2016. Visible light assisted improved photocatalytic activity of combustion synthesized spongy- $\mathrm{ZnO}$ towards dye degradation and bacterial inactivation. RSC Adv, $6,1-31$.

2. Ahmad A., Bahruddin, Said Z.A., David A. 2012. Uji kinerja bioreaktor hybrid anaerob dalam mengolah limbah cair pabrik kelapa sawit dengan beban kejut. Prosiding Seminar Nasional dan Kongres MAKSI 2012 Bogor.

3. Akpan U.G., Hameed B.H. 2009. Parameters affecting the photocatalytic degradation of dyes using TiO2-based photocatalysts: a review. J. of Hazardous Materials, 170(2), 520-529.

4. Alhaji M.H., Sanaullah K., Fong L.S., Khan A., Hipolito C.N., Abdullah M.O., Bhawani S.A., Jamil T. 2016. Photocatalytic Treatment technology for palm oil mill effluent (POME) A review. Process safety and environment protection. http://dx.doi. org/10.1016/j.psep.2016.05.020
5. Ali A.M et al. 2014. Preparation and characterization of $\mathrm{ZnO}-\mathrm{SiO} 2$ thin films as highly efficient photocatalyst. J. of Photochemistry and Photobiology A: Chemistry, 275, 37-46.

6. Amini M., Ashrafi M. 2016. Photocatalytic degradation of some organic dyes under solar light irradiation using $\mathrm{TiO}_{2}$ and $\mathrm{ZnO}$ nanoparticles Nano. Chem. Res, 1, 79-86.

7. Bandeira M., Marcelo G., Mariana R., Ely, Declan M.D., Janaina da S.C. 2020. Green synthesis of zinc oxide nanoparticles: A review of the synthesis methodology and mechanism of formation. Sustainable Chemistry and Pharmacy, 15, 100223.

8. Rahayu A.S., Kharsiwulan D., Yuwono H., Trisnawati I., Mulyasari S., Rahardjo S., Hokermin S., Paramita V. 2015. Konversi POME menjadi biogas, prospek pengembangan di Indonesia. WinRock International.

9. Chang Chih-Yi, Nae-Lih W. 2010. Process Analysis on Photocatalyzed Dye Decomposition for Water Treatment with TiO2-Coated Rotating Disk Reactor. Ind. Eng. Chem. Res., 49, 12173-12179. https://doi. org/10.1021/ie101330n

10. Chang S.H. 2014. An overview of empty fruit bunch from oil palm as feedstock for bio-oil production. Biomass and Bioenergy, 62. 174-181.

11. Chokriwal A. et al. 2014. Biological Synthesis of Nanoparticles Using Bacteria and Their Applications. 4(6).

12. Claes T., Anouk D.M.E.L., Tom V.G. 2019. Translucent packed bed structures for high throughput photocatalytic reactors. Chemical Eng. Journal, 361, 725-735. https://doi.org/10.1016/j.cej.2018.12.107.

13. Doss N., Gaëlle C., Valérie K., Philippe A., Nicolas K. 2018. Photocatalytic Decontamination of Airborne T2 Bacteriophage Viruses in a SmallSize TiO2/ $\beta$-SiC Alveolar Foam LED Reactor. J. of Water, air \& soil pollution, 229, 29. https://doi. org/10.1007/s11270-017-3676-y

14. Fadzil N.A.M., Zulkarnain Z., Abdul H.A. 2013. COD Removal for Palm Oil Mill Secondary Effluent by Using UV/Ferrioxalate/TiO2/O3 system. Int $\mathrm{J}$ of Emerging Technology and Advanced Engineering, 3(7).

15. Fajaroh F. 2018. Sintesis Nanopartikel dengan Prinsip Kimia Hijau. Prosiding Seminar Nasional Kimia dan Pembelajarannya (SNKP), 24-32.

16. Fathinia M., Khataee A.R. 2013. Residence time distribution analysis and optimization of photocatalysis of phenazopyridine using immobilized $\mathrm{TiO} 2$ nanoparticles in arectangular photoreactor. J. of Industrial and Engineering Chemistry, 19(5), 22, 1525-1534.

17. Ghazali S.S., Jusoh R., Shariffuddin J.H. 2018. Parameter affecting photocatalytic degradation of 
POME using LaCa as photocatalyst. Materials Today: proceedings, 19, 1173-1182.

18. Ghosh P.R., Derek F., Shashi B.S., Gerrard E.J.P. 2017. Production of High-Value Nanoparticles via Biogenic Processes Using Aquacultural and Horticultural Food Waste Material. 10, 852 doi:10.3390/ ma10080852

19. Herrmann J.M. 2005. Heterogeneous photocatalytic: state of the art and present applications In honor of Pr. RL Burwell Jr. (1912-2003). Former Head of Ipatieff Laboratories Northwestern University Evanston (Ill) Topics in Catalysis, 34, 49-65.

20. Ibhadon A.O., Fitzpatrick P. 2013. Heterogeneous photocatalytic: recent advances and applications. Catalysts, 3(1), 189-218.

21. Jamali A., Richard V., Peter H., Tom V.G. 2013. A batch LED reactor for the photocatalytic degradation of phenol. Chemical Engineering and Processing: Process Intensification, 71, 43-50. http:// dx.doi.org/10.1016/j.cep,201303.010

22. Jo W., Rajesh J.T. 2016. Facile photocatalytic reactor development using nano-TiO2 immobilized mosquito net and energy efficient UVLED for industrial dyes effluent treatment. J. of Environmental Chemical Engineering, 4, 319-327. https://doi. org/10.1016/j.jece.2015.11.024

23. Kanmani S., Sundar K.P. 2019. Progression of Photocatalytic reactors and it's comparison: A Review Chemical Engineering Research and Design. doi: https://doi.org/10.1016/j.cherd.2019.11.035

24. Kee M.W., Lam S.M., Sin J.C., Zeng H., Mohamed A.R. 2019. Explicating charge transfer dynamics in anodic $\mathrm{TiO} 2 / \mathrm{ZnO} / \mathrm{Zn}$ photocatalytic fuel cell for ameliorated palm oil mill effluent treatment and synchronized energy generation. J. of Photochemistry and amp; Photobiology, A: Chemistry. doi: https:// doi.org/10.1016/j.jphotochem.2019.112353

25. Khademalrasool M., Mansoor F., Mohammad D.T. 2016. The improvement of photocatalytic processes: Design of a photoreactor using high-power LEDs. J. of Science: Advanced Materials and Devices, 1, 382-387. http://dx.doi.org/10.1016/j. jsamd.2016.06.012

26. Khan M.M., Adil S.F., Al-Mayouf A. 2015. Metal oxides as photocatalysts. J. of Saudi Chemical Society. http://dx.doi.org/10.1016/j.jscs.2015.04.003

27. Kumari P., Bahadur N., Dumee L.F. 2020. Photocatalytic membrane reactor for the remediation of persistent organic pollutant: A review Separation and Purification technology, 230, 115878.

28. Lazar M.A., Varghese S., Nair S.S. 2012. Photocatalytic Water Treatment 1 by Titanium Dioxide. Recent Updates Catalysts, 2, 572-601.

29. Lestari L. 2017. Degradasi senyawa organik pada palm oil mill secondary effluent menggunakan fotokatalis TiO2. J. Citra Widya Edukasi IX, (2).

30. Li D. et al. 2014. A novel double-cylindrical-shell photoreacto $+\mathrm{r}$ immobilized with monolayer TiO2coated silica gel beads for photocatalytic degradation of Rhodamine B and Methyl Orange in aqueous solution. Separation and Purification Technology, 123, 130-138.

31. Meunier S.M., Joanne G., Zdravko D., Zisheng Z. 2010. Design and Characterization of a Novel Rotating Corrugated Drum Reactor for Wastewater Treatment. Int. J. of Photoenergy, 6, 10.1155/2010/146743.

32. Mirzaei M., Morteza J., Bahram D., Mitra D. 2017. Evaluation and modeling of a spinning disc photoreactor for degradation of phenol: impact of geometry modification. J. of Photochemistry and photobiology A: Chemistry, 346, 206-214. http://dx.doi.org/ doi:10.1016/j.jphotochem.2017.05.043

33. Muthuvinothini A., Stella S. 2018. Green synthesis of Metal Oxide nanoparticles and their catalytic activity for the reduction of aldehydes. Process Biochemistry. https://doi.org/10.1016/j.procbio.2018.12.001

34. Natarajan K., Thillai S.N., Bajaj H.C., Rajesh J.T. 2011. Photocatalytic reactor based on UV $\mathrm{LED} / \mathrm{TiO} 2$ coated quartz tube for degradation of dyes. Chemical Engineering Journal, 178, 40-49 10.1016/j.cej.2011.10.007

35. Nickels P., Hang Z., Sulaiman N.B., Abdullah Y.O., Tarek T.A., Ahmed A.A., El-Sayed H.E., Abdulrahman O.A., Stephen A.L. 2012. Laboratory Scale Water Circuit Including a Photocatalytic Reactor and a Portable In-Stream Sensor To Monitor Pollutant Degradation. Industrial \& Engineering Chemistry Research, 51, 3301-3308 https://doi.org/10.1021/ ie $202366 \mathrm{~m}$

36. Ng K.H. et al. 2015. Photocatalytic degradation of Recalcitrant POME Waste by Using Silver Doped Titania. Photokinetics and Scavenging Studies Chemical Engineering Journal.

37. Ng K.H., Yuan L.S., Cheng C.K., Chen K., Fang C. 2019. $\mathrm{TiO} 2$ and $\mathrm{ZnO}$ photocatalytic treatment of palm oil mill effluent (POME) and feasibility of renewable energy generation: A short review. J. of Cleaner production, 233, 209-225.

38. Ong C.B., Mohammad W., Rohani R., Ba-Abbad M.M., Hairom N.H.H. 2016. Solar photocatalytic degradation of hazardous Congo red using low temperature synthesis of zinc oxide nanoparticles. Process Safety and Environment Protection. http:// dx.doi.org/10.1016/j.psep.2016.04.006

39. Passalía C., Orlando M.A., Rodolfo J.B. 2013. Optimal Design of a Corrugated-Wall Photocatalytic Reactor Using Efficiencies in Series and Computational Fluid Dynamics (CFD) Modeling. Industrial \& Engineering Chemistry Research, 52, 6916-6922. https://doi.org/10.1021/ie302838m 
40. Qi N. et al. 2011. CFD modelling of hydrodynamics and degradation kinetics in an annular slurry photocatalytic reactor for wastewater treatment. Chemical Engineering Journal, 172(1), 84-95.

41. Rekhaa R., Mani D., Marimuthu G., Naiyf S.A., Shine K., Jamal M.K., Mohammed N.A., Roman P., Baskaralingam V. 2019. Synthesis and characterization of crustin capped titanium ioxide nanoparticles: Photocatalytic, antibacterial, antifungal and insecticidal activities. J. of Photochemistry \& Photobiology B: Biology, 199, 111620.

42. Sacco O., Mariantonietta M., Vincenzo V., Giovanni L., Marco G., Giusy L., Maurizio C. 2018. Crystal violet and toxicity removal by adsorption and simultaneous photocatalytic in a continuous flow micro-reactor. Science of the Total Environment, 644, 430-438.

43. Salsabila F. 2016. Pengolahan air dan limbah dengan reaktor membran fotokatalitik. https:/www. researchgate.net/publication/303303470

44. Santiago D.E. et al. 2015. Photocatalytic treatment of water containing imazalil using an immobilized TiO2 photoreactor. Applied Catalysis A: General, 498, 1-9. Available at: http://linkinghub.elsevier. com/retrieve/pii/S0926860X15001799

45. Sarono, Suparno O., Suprihatin, Hasanudin U. 2016. The performance of biogas production from POME at different temperature. Int. J. of technology, 8, 1413-1421.

46. Shah M., Derek F., Shashi S., Suraj K.T., Gérrard E.J.P. 2015. Green Synthesis of Metallic Nanoparticles via Biological Entities. Materials, 8, 72787308. doi:10.3390/ma8115377

47. Sidik D.A.B., Nur H.H.H., Abdul W.M. 2019. Performance and fouling assessment of different membrane types in a hybrid photocatalytic membrane reactor (PMR) for palm oil mill secondary effluent (POMSE) treatment. Process Safety and Environment Protection, 130, 265-274.

48. Subramaniam M.N., Goh P.S., Lau W.J., Ng B.C., Ismail A.F. 2017. AT-POME colour removal through photocatalytic submerged filtration using antifouling PVDF-TNT nanocomposite membrane. Separation and Purification Technology. doi: https://doi. org/10.1016/j.seppur.2017.09.042

49. Sugiyana D., Suprihanto N. 2015. Studi mekanisme degradasi fotokatalitik zat warna Azo acid red 4 menggunakan katalis mikropartikel TiO2. Arena Tekstil, 30(2).

50. Tabassum S., Zhang Y., Zhang Z. 2015. An integrated method for palm oil mill effluent (POME) treatment for achieving zero liquid discharge - A pilot study. Journal of Cleaner Production, 95, 148-155.

51. Tan Y.H. et al. 2014. Treatment of Aerobic Treated Palm Oil Mill Effluent (AT-POME) by using TiO2 Photocatalytic Process. J. Teknologi, 70(2).

52. Thota S., Tirokkovalluri S.V., Boojja S. 2014. Visible light induced photocatalytic degradation of methyl red codoped with titania. J. of Catalyst. http://dx.doi.org/10.1155/2014/962419

53. Vaiano V., Sacco O., Pisano D., Sannino D., Ciambelli P. 2015. From the design to the development of a continuous fixed bed photoreactor for photocatalytic degradation of organic pollutants in wastewater. Chemical Engineering Science, 137, 152-160. http://dx.doi.org/10.1016/j.ces.2015.06.023

54. Vela N. et al. 2014. Photocatalytic mitigation of triazinone herbicide residues using titanium 3 dioxide in slurry photoreactor. Catalysis Today.

55. Vijayaraghavan K., Ahmad D., Aziz M.E.B.A. 2007. Aerobic treatment of palm oil mill effluent. Journal of environmental management, 82(1), 24-31.

56. Visan A., Damon R., Wojciech O., Rob G.H.L. 2014. Modeling intrinsic kinetics in immobilized photocatalytic. Microreactors Applied Catalysis B: Environmental, 150-151, 93-100.

57. Visan A.J., Ruud van O., Michiel T.K., Rob G.H.L. 2019. Photocatalytic Reactor Design: Guidelines for Kinetic Investigation. Ind. Eng. Chem. Res, 58, 5349-5357.

58. Wang J. et al. 2015. Anaerobic Treatment of Palm Oil Mill Effluent in Pilot-Scale Anaerobic EGSB Reactor. BioMed Research International.

59. Xing Y.X., Li L., Zhang Q., Xu Z., Che W., Li Y., Bai K.L. 2012. Effect of TiO2 nanoparticles on the antibacterial and physical properties of polyethylenebased film. Prog. Org. Coat, 73, 219-224.

60. Yurdakal S., Vittorio L., Giovanni P., Vincenzo A., Huseyin B., Leonardo P. 2010. Kinetics of 4-Methoxybenzyl Alcohol Oxidation in Aqueous Solution in a Fixed Bed Photocatalytic Reactor. Ind. Eng. Chem. Res., 49, 6699-6708. https://doi. org/10.1021/ie9008056

61. Zainuri N.Z., Nur H.H.H., Dilaelyanam A.B.S., Amira L.D., Nurasyikin M., Norhaniza Y., Abdul W.M. 2018. Palm oil mill secondary effluent (POMSE) treatment via photocatalytic process in presence of ZnO-PEG nanoparticles. J. of Water Process Engineering, 26, 10-16.

62. Zhang Z., Hongjun W., Yuan Y., Yanju F., Litong J. 2012. Development of a novel capillary array photocatalytic reactor and application for degradation of azo dye. Chemical Engineering Journal, 184. 9-15. 10.1016/j.cej.2011.02.057 